\title{
Prognostic value of MYD88 L265P mutation in diffuse large B cell lymphoma via droplet digital PCR
}

\author{
JING NIU $^{1,2^{*}}$, ZHIPING MA $^{1 *}$, AIJIANG NUERLAN ${ }^{1,2}$, SIJING LI $^{1,2}$, WENLI CUI ${ }^{1}$, HAIXIA GAO ${ }^{1,2}$, \\ GULINAER ABULAJIANG ${ }^{1}$, WEI ZHANG ${ }^{1}$ and XINXIA LI ${ }^{1}$ \\ ${ }^{1}$ Department of Pathology, The First Affiliated Hospital of Xinjiang Medical University, \\ Urumqi, Xinjiang Uygur Autonomous Region 830054; ${ }^{2}$ The First Clinical Medical College, \\ Xinjiang Medical University, Urumqi, Xinjiang Uygur Autonomous Region 830011, P.R. China
}

Received September 25, 2019; Accepted May 5, 2020

DOI: $10.3892 / \mathrm{mmr} .2020 .11186$

\begin{abstract}
To assess the prevalence and prognostic value of myeloid differentiation factor 88 (MYD88) expression and mutational status in diffuse large B cell lymphoma (DLBCL), a total cohort of 100 patients with DLBCL were studied using immunohistochemistry (IHC) and droplet digital polymerase chain reaction (DDPCR), and the association between MYD88 expression and clinicopathological parameters was analyzed. Overall, the positive expression rate of MYD88 protein was $38 \%$ and the gene mutation rate was $29 \%$. The positive expression and mutation rates were the highest in the primary central nervous system lymphomas (58.33 and 66.67\%, respectively). The coincidence rate of the results of MYD88 expression between IHC and DDPCR results was $73 \%$ (73/100). Univariate survival analysis showed that age ( $\geq 60$ years old), high neutrophil/lymphocyte count ratio, low lymphocyte count, c-Myc $\geq 40 \%$, positive MYD88 protein expression, and gene mutation were associated with poorer prognosis rates. Multivariate survival analysis revealed that MYD88 expression was an independent prognostic factor affecting overall survival. In conclusion, the results of this study demonstrated that MYD88 mutation was a valuable index to evaluate the prognosis of DLBCL. DDPCR can be used as a method for detecting MYD88 mutations, although it was not completely consistent with the results of IHC.
\end{abstract}

\section{Introduction}

Diffuse large B cell lymphoma (DLBCL) is the most common type of adult lymphoma (1). B cell lymphomas are hetero-

Correspondence to: Professor Xinxia Li, Department of Pathology, The First Affiliated Hospital of Xinjiang Medical University, 137 Liyushan Southern Road, Urumqi, Xinjiang Uygur Autonomous Region 830054, P.R. China

E-mail: 1xx-patho@163.com

${ }^{*}$ Contributed equally

Key words: NF-кB pathway, diffuse large B cell lymphoma, myeloid differentiation factor 88 L265P, droplet digital PCR, immunohistochemistry, prognosis geneously categorized in terms of clinical manifestations, histomorphology, immunophenotyping and prognosis (1). Our group has recorded 1,831 lymphoma cases between 2008 and 2018 (data not published). Of the non-Hodgkin lymphoma, the most common type was DLBCL (45.6\%; 741/1,625), which is higher than that of the China and other Western countries (30-35\%) (2-4). According to the cell-of-origin classification, DLBCL can be divided into two main molecular subtypes, defined by gene expression profiling: Germinal center B cell like (GCB), Activated B cell like (ABC) $(5,6)$. DLBCL often involves various nodal and extranodal sites. There are a number of large B cell lymphoma (LBCL) subtypes, including primary central nervous system (PCNSL), primary testicular lymphoma (PTL) and primary mediastinal B cell lymphoma (PMBL) (7-9).

A combined treatment regimen of rituximab, cyclophosphamide, doxorubicin, vincristine and prednisone (R-CHOP) can significantly improve the prognosis of most patients (10). However, due to individual differences and tumor cell resistance, recurrence occurs in one-third of patients, causing them to enter the advanced phase of DLBCL after treatment (11). Increased interest in DLBCL led to Ngo et al (12) to discover the role of myeloid differentiation factor 88 (MYD88) L265P as a disease-relevant driver gene. MYD88 is a soluble adaptor protein in the cytoplasm for inflammatory signaling pathways downstream of members of the Toll-like receptor (TLR) and interleukin (IL)-1 that mainly mediates the cellular signal transduction of the TLR, IL-1 receptor (R) and IL-18R, so MYD88 plays a key role in innate immunity (13-15). Ngo et al (12) found that in DLBCL, L265P mutation occurs at position 794 of the coding sequence of MYD88, resulting in the missense mutation of leucine to proline at position 265 in the coding region of MYD88 protein, which abnormally activates the IL-1R-mediated NF- $\kappa$ B, MAPK and JAK-STAT3 signaling pathways, and leads to tumorigenesis (16).

Subsequently, it was demonstrated that the MYD88 mutation can be used to identify a molecular subgroup of patients with DLBCL that have poorer prognosis rates (17). MYD88 L265P mutation also occurs in a subtype of PCNSL associated with poor prognosis $(18,19)$. Pham-Ledard et al $(20)$ found that the gene mutation rate was 59\% in DLBCL, leg type (DLBCL-LT), and the prognosis was poor. Furthermore, Kraan et al (21) found 
the MYD88 mutation in 68\% of PTL tumors analyzed. MYD88 L265P mutations have also been observed in other hematological diseases, such as lymphoplasmacytic lymphoma/Waldenström's macroglobulinemia, IgM monoclonal gammopathy of undetermined significance, marginal zone lymphoma and chronic lymphocytic leukemia (22-24).

Schmitz et al (25) found four DLBCL genotype subtypes, namely, MCD (based on the co-occurrence of MYD88, L265P and CD79B mutations), BN2 (based on BCL6 fusions and NOTCH2 mutations), N1 (based on NOTCH1 mutations) and EZB (based on EZH2 mutations and BCL2 translocations), and poorer prognosis rates in patients with MCD and N1 subtypes. Weber et al (26) proposed immunotherapy for MYD88 L265P mutant tumors. It has been hypothesized that DLBCL could be treated with MYD88 L265P peptide as a novel tumor-specific antigen to induce cytotoxic $\mathrm{T}$ cell reaction (26). Hence, developing therapeutic agents for this mutation is becoming increasingly important.

The frequency of MYD88 mutations at the protein and molecular level was assessed in tumor tissue samples from 100 patients diagnosed with DLBCL, following which a correlation analysis was performed to analyze clinicopathological characteristics. Therefore, this study provides a comprehensive summary of the methods used to detect MYD88 at different levels of expression, and explores the prognostic value of MYD88 and other clinicopathological parameters in DLBCL.

\section{Materials and methods}

Study cohort. Tumor tissues were collected from 100 patients with DLBCL at The First Affiliated Hospital of Xinjiang Medical University (Urumqi, China) and considered as formaldehyde-fixed paraffin-embedded (FFPE) archival specimens between August 2010 and July 2018. According to the 2016 World Health Organization diagnostic criteria of hematopoietic and lymphoid tissue tumors (27), two senior pathologists (Professor Xinxia Li and Professor Wei Zhang) reviewed the cases and collected clinicopathological data in the Department of Pathology of The First Affiliated Hospital of Xinjiang Medical University. Patients were followed up for 79 months. The study protocol was approved by the Ethics Review Board of The First Affiliated Hospital of Xinjiang Medical University. Written informed consent was obtained from participants. All of the procedures were performed in accordance with the Declaration of Helsinki and relevant policies in China (28).

Immunohistochemistry (IHC). A total of 100 FFPE tissue samples from patients with DLBCL were immersed in $4 \%$ paraformaldehyde for $4 \mathrm{~h}$ at room temperature and assembled into a tissue microarray with a core diameter of $2 \mathrm{~mm}$, cut to a thickness of $3 \mu \mathrm{m}$, and heat treated with EDTA antigen retrieval solution ( $\mathrm{pH}=8.0$; cat. no. ZLI-9079; Beijing Zhongshan Golden Bridge Biological Technology Co., Ltd.) for $20 \mathrm{~min}$. Samples were blocked with $3 \%$ peroxide-hydrogen for $10 \mathrm{~min}$ at room temperature for endogenous peroxidase ablation and then incubated with the mouse anti-MYD88 (1:700; cat. no. ab133739; Abcam) and diluted in PBS (0.01 M PBS, pH=7.4), for $1 \mathrm{~h}$ at $37^{\circ} \mathrm{C}$. Secondary antibody (anti-mouse IgG; cat. no. PV-6000; Beijing Zhongshan Golden Bridge Biological Technology Co., Ltd.) was then added and incubated for $30 \mathrm{~min}$ at $37^{\circ} \mathrm{C}$.
Coloration with 3,3-diaminobenzidin was performed at room temperature in the dark for $10 \mathrm{~min}$. MYD88 was localized in the cytoplasm of lymphoma cells. IHC analysis (Leica DM3000; light microscope; magnification, $\mathrm{x} 40$ ) was based on the immunohistochemical scoring system (29), which was classified into negative and positive. Staining intensity was scored as follows: i) 0 , negative; ii) 1 , weak; iii) 2 , moderate; iv) 3 , intense. The extent of staining was scored as follows: i) $0,0 \%$ of tumor area stained; ii) $1,<10 \%$; iii) $2,10-50 \%$; iv) $3,>50 \%$. These two scores were summed to give each sample a final score ranging from 0 to 6 . The final scores of 0 to 1 and 2 to 6 were considered as negative and positive MYD88 expression, respectively.

Other related immunohistochemical markers were examined using a Roche VENTANA Benchmark XT automated immunohistochemical staining instrument (Roche Diagnostics). The primary antibodies used against p53, CD10, CD30, myeloma-associated antigen-1 (MUM-1), Bcl-2, c-Myc, CD20, Bcl-6 and proliferation marker protein Ki-67 (Ki-67) are presented in Table SI. The specific details of the experimental method for these other related immunohistochemical markers are the same as aforementioned for the MYD88 antibody incubation.

DNA isolation. FFPE tissues were cut into $10 \mu \mathrm{m}$-thick sections, and the most lymphoma-cell-rich area was dissected using a scalpel. Total genomic DNA was subsequently extracted with a QIAamp DNA FFPE tissue kit (cat. no. 56404; Qiagen, Inc.), according to the manufacturer's instructions, and was quantified spectrophotometrically using an Invitrogen Qubit 2.0 Fluorometer (Thermo Fisher Scientific, Inc.). The concentration and optical density ratio of the DNA solution were calculated using a Quawell Q5000 UV-Vis Spectrophotometer (Quawell Technology, Inc.). All samples were immediately stored at $-80^{\circ} \mathrm{C}$ for further analysis.

Droplet digital polymerase chain reaction (DDPCR) for the detection of MYD88 L265P mutation. The Bio-Rad QX200 Droplet Digital PCR system (Bio-Rad Laboratories, Inc.) was used to perform DDPCR. The primers of MYD88 were synthesized by Shanghai Yuanqi Biomedical Technology Co., Ltd., as follows: Forward, 5'-CTTGGCTTGCAGGTGCC-3' and reverse, 5'-CTTTCTTCATTGCCTTGTACTTGATG-3' (amplified fragment size of 63 base pairs). In each DDPCR reaction, two probes were used (Invitrogen; Thermo Fisher Scientific, Inc.), a FAM-labeled probe for the MYD88 L265P mutation (5'-FAM-AGA AGC GAC CGA TCC-MGB-BHQ-3') and a VIC-labeled probe for the MYD88 L265P wild-type allele (5'-VIC-AGA AGC GAC TGA TCC-MGB-BHQ-3'). The reaction volume was $20 \mu 1$ (4 $\mu$ l DDPCR reaction solution, $10 \mu 1$ DDPCR mix 3,6 $\mu 1$ template). PCR was performed in a Veriti $^{\mathrm{TM}}$ Thermal Cycler (Thermo Fisher Scientific, Inc.) using the following conditions: $95^{\circ} \mathrm{C}$ for $10 \mathrm{~min}$; followed by 40 cycles of $94^{\circ} \mathrm{C}$ for $15 \mathrm{sec}$ and $58^{\circ} \mathrm{C}$ for $60 \mathrm{sec}$; and a final extension at $98^{\circ} \mathrm{C}$ for $10 \mathrm{~min}$. After thermocycling, the 96 -well plate was put in the plate holder and read in the QX200 Droplet Digital PCR system, and based on positive droplets and according to the Poisson distribution, the absolute copy number of the MYD88 L265P and wild-type MYD88 alleles was calculated using QuantaSoft $^{\mathrm{TM}}$ analysis software (version 1.7.4.0917; Bio-Rad Laboratories, Inc.). The positive control was a plasmid and the 

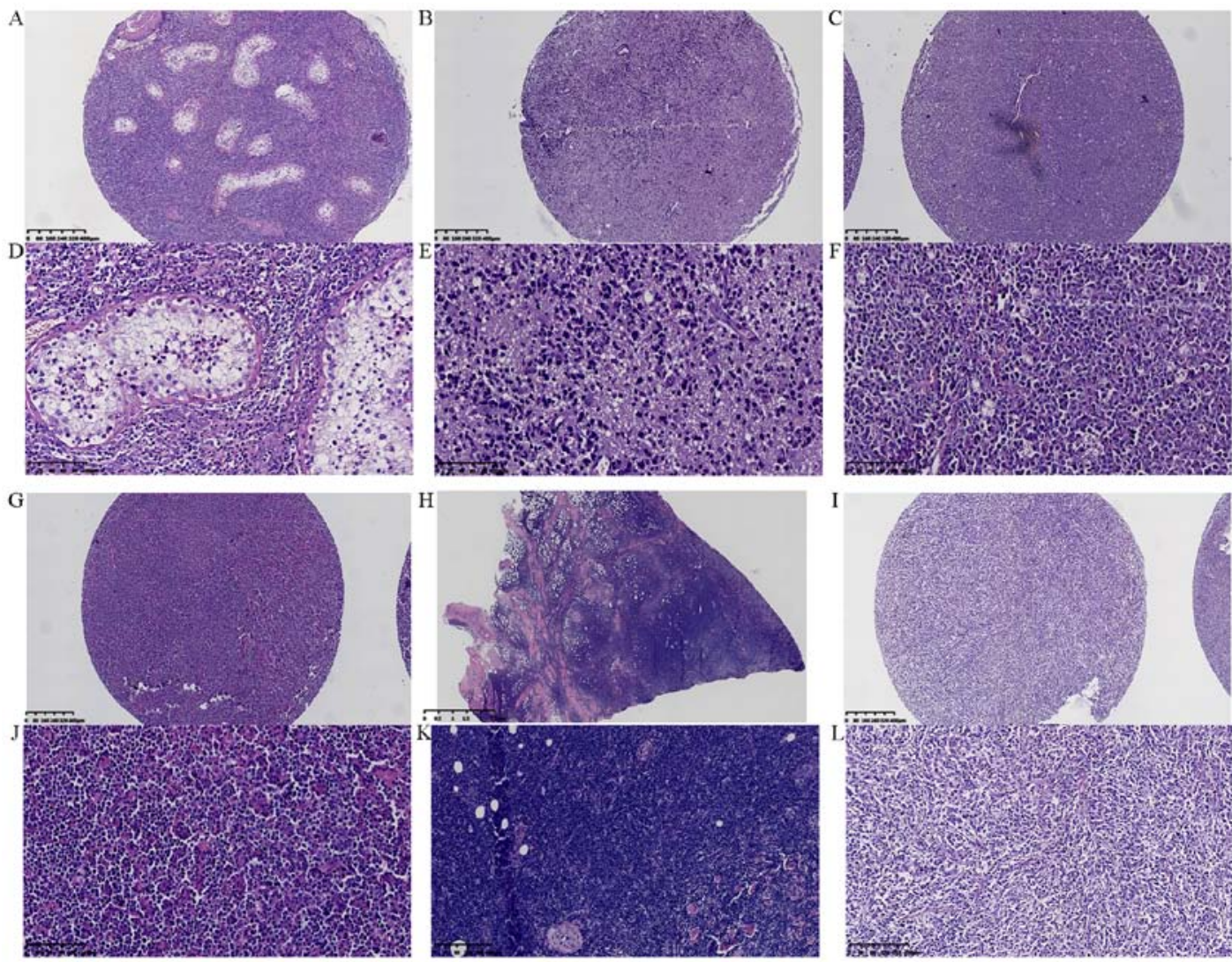

Figure 1. Morphological observation of lesions in various sites of diffuse large B cell lymphoma by hematoxylin and eosin staining. (A) Testis at magnification, $\mathrm{x} 40$. (B) Central nervous system at magnification, $\mathrm{x} 40$. (C) Lymph node at magnification, $\mathrm{x} 40$. (D) Testis at magnification, x200. (E) Central nervous system at magnification, x200. (F) Lymph node at magnification, x200. (G) Tongue at magnification, x40. (H) Skin at magnification, x40. (I) Gastrointestinal tract at magnification, x40. (J) Tongue at magnification, x200. (K) Skin at magnification, x100. (L) Gastrointestinal tract at magnification, x100.

negative control was distilled water. The following method was used to judge whether expression was positive or negative: i) Positive, mutation frequency $\geq 1 \%$ and $\geq 3$ droplets fall in the 'Ch1+Ch2-' region; ii) negative, $<3$ droplets fall in the ' $\mathrm{Ch} 1+$ ' region and $<5$ droplets fall in the ' $\mathrm{Ch} 2+$ ' region [Ch1, mutation copy number; Ch2, wild-type copy number; Ch1+Ch2, genomic DNA copy number; and Ch1/(Ch1+Ch2), mutation frequency]. Green droplets depict wild-type droplets (Ch1-/Ch2+) region, gray droplets depict negative droplets without detectable DNA (Ch1-/Ch2-) region and orange droplets depict double positive droplets $(\mathrm{Ch} 1+/ \mathrm{Ch} 2+)$ region.

Routine blood tests. Routine blood tests were measured using overnight fasting blood samples $(1 \mathrm{ml})$ collected from an antecubital vein between 7 am and 9 am, drawing the blood into a test tube containing an anticoagulant (EDTA) to prevent clotting. The measurement of blood components was automated using an automatic blood cell analyzer (cat. no. BC5000; Shenzhen Mindray Bio-Medical Electronics Co., Ltd.; https://www. mindray.com/au/index.html). Blood tests were used to measure blood components, such as monocyte, neutrophil, lymphocyte, platelet and hemoglobin.

Statistical analysis. Statistical analyses were performed using SPSS 17.0 software (SPSS, Inc.). Chi-square test was conducted to analyze the correlation between clinicopathological parameters and indicators. Progression-free survival (PFS) was calculated as the time since the date of diagnosis. Overall survival (OS) was determined as the date of diagnosis to the date of death by any cause. PFS and OS were determined through univariate (Kaplan-Meier) and multivariate analyses (Cox proportional hazard model) for survival analysis and survival curve mapping. Data for crossing of survival curves were analyzed using the statistical packages R (The R Foundation; http://www.r-project. org; version 3.4.3) and Empower R (www.empowerstats.com; $\mathrm{X} \& \mathrm{Y}$ solutions, Inc.). $\mathrm{P}<0.05$ was considered to indicate a statistically significant difference.

\section{Results}

Clinicopathological characteristics. A total of 100 patients with DLBCL were included in the present study, this consisted of 41 female participants and 59 male participants with a median age of 59 years (25-88 years). Among them, 37\% (37/100) had DLBCL in the lymph nodes and 63.0\% (63/100) had DLBCL in extranodal sites. The central nervous system(CNS) was the most common extranodal site in the patients of the present study $(24 / 63$, $38.1 \%$ ). Nine patients had a gastrointestinal tract lesion (14.29\%), eight had head and neck lesions (12.70\%), five had retroperitoneal lesions (7.94\%), four had soft tissue lesions (6.35\%), four had joint lesions (6.35\%), three had testicular lesions (4.76\%), and six patients had breast, kidney, adrenal gland, uterus, spleen and skin cases $(1.59 \%, 1 / 63)$ (Fig. 1A-L). Routine blood tests were used to measure lymphocytes, monocytes, neutrophils, hemoglobin and platelet counts. Lymphocyte/monocyte count ratio (LMR) and neutrophil/lymphocyte count ratio (NLR) 


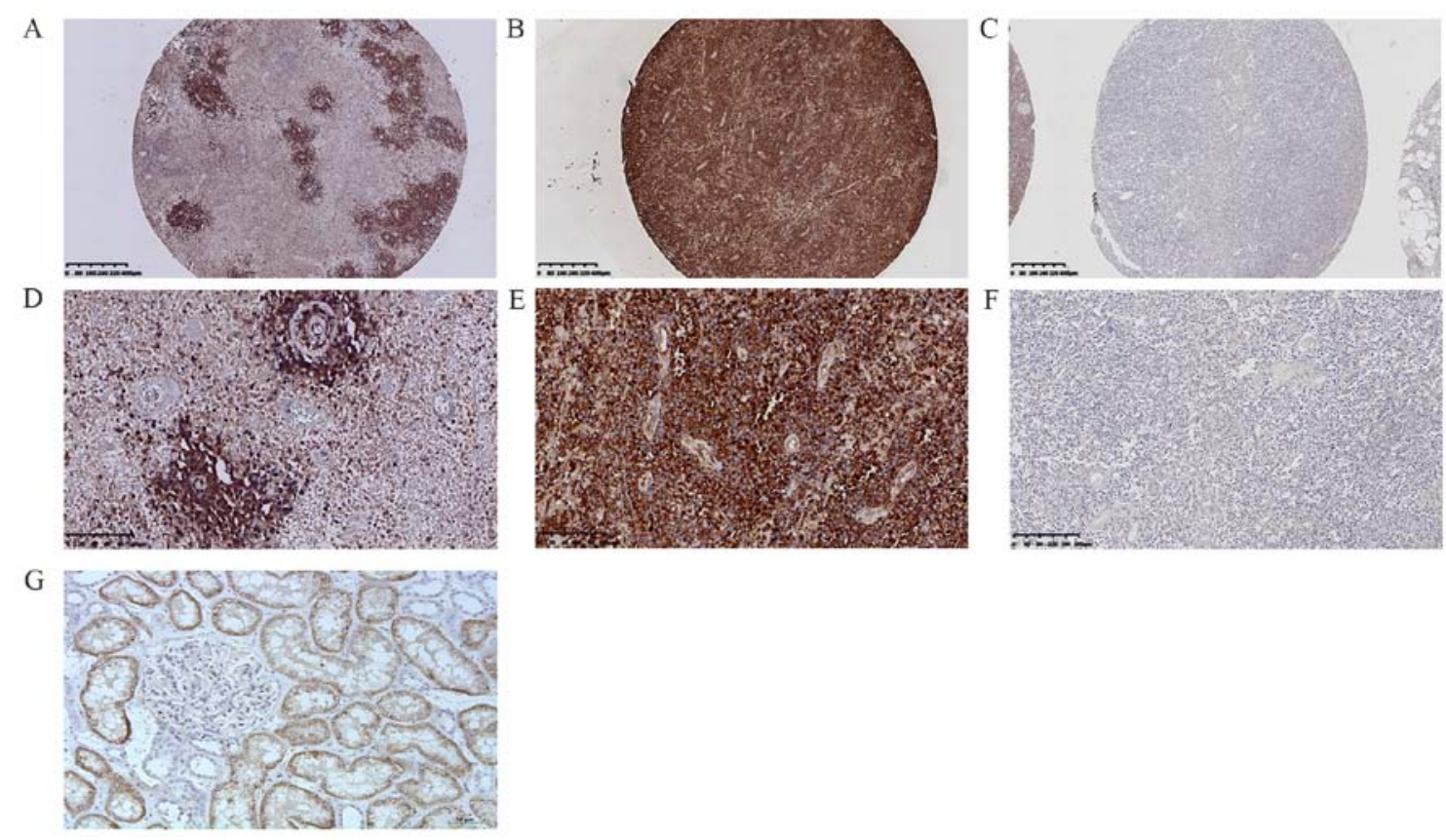

Figure 2. Immunohistochemistry staining for MYD88 in diffuse large B cell lymphoma specimens. (A) MYD88 expression in tumor cells surrounding blood vessels at magnification, $\mathrm{x}$ 40. (B) Positive expression of MYD88 (cytoplasm) at magnification, $\mathrm{x} 40$. (C) Negative expression of MYD88 at magnification, $\mathrm{x} 40$. (D) MYD88 expression in tumor cells surrounding blood vessels at magnification, x200. (E) Positive expression of MYD88 (cytoplasm) at magnification, x200. (F) Negative expression of MYD88 at magnification, x100. (G) MYD88 protein positive control tissue (human kidney tissue) at magnification, x200. MYD88, myeloid differentiation factor 88 .

were set at 2.71 and 2.81 , respectively, to assess the prognosis of patients (30). The baseline clinical characteristics of 100 patients with DLBCL in this study are shown in Table SII.

IHC of patients with DLBCL. The patients were divided into 64 cases of ABC subtype DLBCL (ABC-DLBCL; $64 \%, 64 / 100)$ and 36 cases of GCB subtype DLBCL (GCB-DLBCL; 36\%, 36/100) using the Hans classification scheme (ABC:GCB; 1.8:1). Protein expression and gene mutations were investigated in 100 DLBCL cases. First, a frequent rate of protein expression was observed in $38 \%$ of cases (38/100) (Fig. 2A-G). Second, positive MYD88 expression was found in $43.75 \%(28 / 64)$ and $27.78 \%$ (10/36) of ABC-DLBCL and GCB-DLBCL cases, respectively. Positive MYD88 expression was observed in $32.43 \%(12 / 37)$ and $41.27 \%(26 / 63)$ of lymph node DLBCL and extranodal DLBCL cases, respectively. For positive MYD88 expression in extranodal sites of DLBCL, the following data were observed: $22.23 \%$ (14/63) in the CNS, $6.35 \%(4 / 63)$ in the head and neck, $3.17 \%(2 / 63)$ in the joints, $3.17 \%(2 / 63)$ in the testes, $1.59 \%(1 / 63)$ in the gastrointestinal tract, $1.59 \%(1 / 63)$ in the retroperitoneal organs, $1.59 \%(1 / 63)$ in the breast, and $1.59 \%$ (1/63) in the kidney. Positive MYD88 expression was also found in $51.52 \%$ of $\mathrm{Bcl}-2 \geq 70 \%$ cases $(17 / 33)$, $39.62 \%$ of p53 expression cases (21/53), 35.71\% of Bcl-6 expression cases (30/84), $32.14 \%$ of $\mathrm{Ki}-67 \geq 60 \%$ expression cases (27/84), $35.29 \%$ of c-Myc $\geq 40 \%$ cases (12/34), $33.33 \%$ of double expression (DE; c-Myc $\geq 40 \%$ and Bcl-2 $\geq 70 \%$ ) cases (4/12), and $22.22 \%$ of CD30 expression cases (2/9) (Tables I and II; Fig. 3A-L).

Detection of MYD88 L265P mutation in DLBCL. DDPCR was performed on 100 DLBCL cases, and a frequent rate of gene mutations was observed in $29 \%$ of cases (29/100) (Fig. 4A-C). MYD88 L265P was found in 32.81\% (21/64) and 22.22\% (8/36) of ABC-DLBCL and GCB-DLBCL cases, respectively. MYD88 L265P mutation was also observed in $16.22 \%$ (6/37) of nodal DLBCL and 36.5\% (23/63) of extranodal DLBCL. Furthermore, the mutation rate was $25.40 \%(16 / 63)$ in the CNS, $3.17 \%(2 / 63)$ in the head and neck, and 4.76\% (3/63) in the joints. MYD88 L265P mutation was also observed in $39.39 \%$ of Bcl-2 $\geq 70 \%$ cases (13/33), $26.42 \%$ of p53 expression cases (14/53), $25 \%$ of Bcl-6-expression cases (21/84), 28.57\% of Ki-67 $\geq 60 \%$ expression cases (24/84), $23.53 \%$ of c-Myc $\geq 40 \%$ cases (8/34), $16.66 \%$ of DE cases (2/12) and 22.22\% of CD30 expression cases (2/9), $66.67 \%$ of PT-DLBCL cases (2/3). The mutation rate of MYD88 in PCNSL was $66.67 \%(16 / 24)$. Additionally, the coincidence rate $(73 \%$, co-negative $53 \%$, co-positive $20 \%$ ) was analyzed by comparing the IHC and DDPCR detection of protein expression and gene mutation (Fig. S1).The clinical characteristics and follow-up of 29 patients with DLBCL with MYD88 L265P mutation are summarized in Table III.

Follow-up. During the follow-up period of 1-79 months, 45 patients $(45 \%)$ were followed up until they passed away due to lymphoma, 5 patients were lost and 50 patients survived. The median and average survival times were 15 and 26.3 months, respectively. The 3- and 5-year OS rates of patients with DLBCL were $28.42 \%(27 / 95)$ and $16.84 \%$ (16/95), respectively. The average survival time of patients treated with rituximab-based multi-agent chemotherapy was longer (R-CHOP vs. CHOP; 32.5 vs. 23.15 months)

Among patients with positive MYD88 protein expression, 22 patients passed away $(57.89 \%, 22 / 38)$ and 13 survived $(34.21 \%, 13 / 38)$. The median and average survival times were 11 

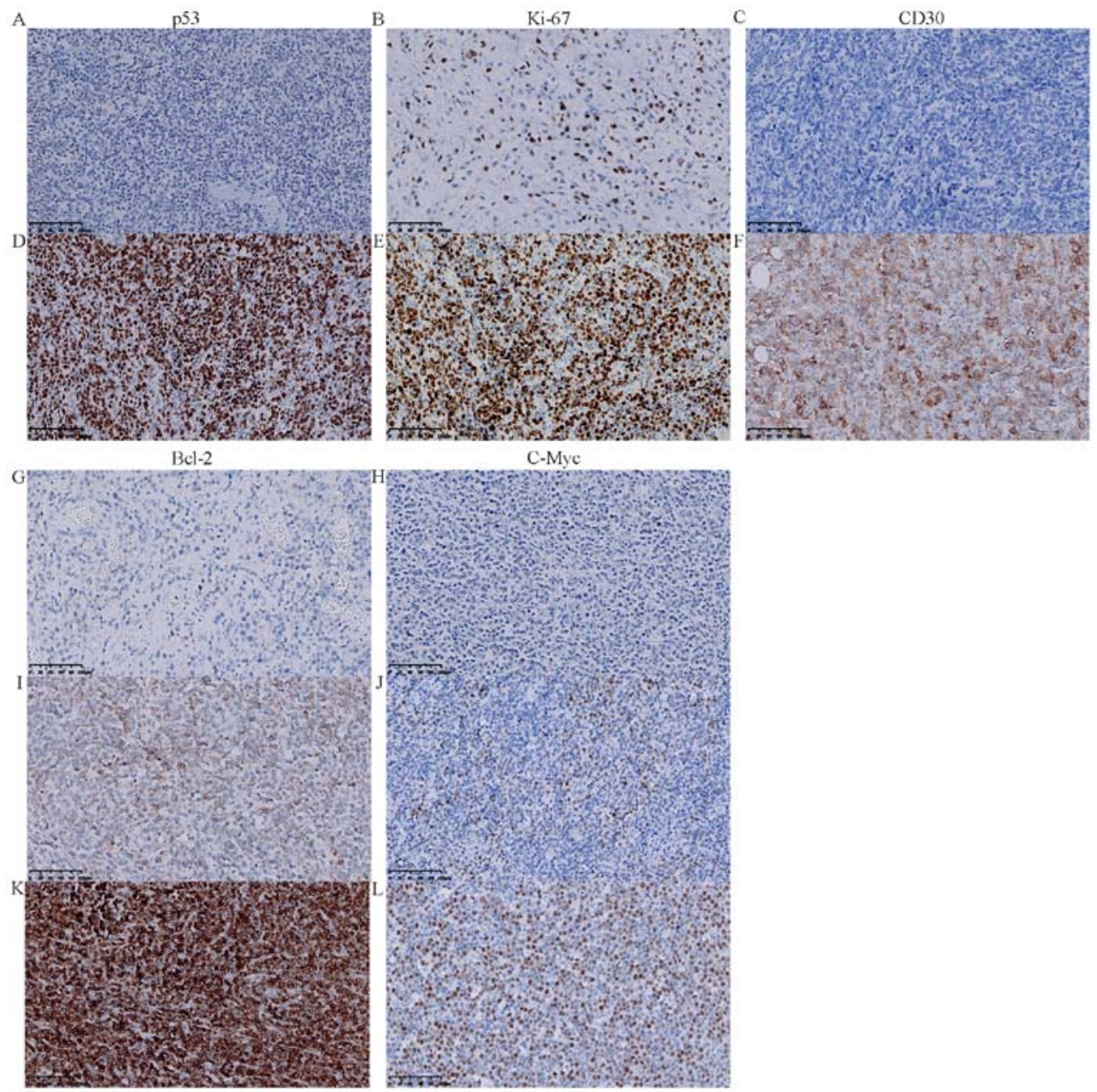

Figure 3. Immunohistochemistry staining for p53, Ki-67, CD30, c-Myc and Bcl-2 in diffuse large B cell lymphoma specimens. (A) Negative expression of p53 (magnification, x200). (B) Low expression of Ki-67 (<80\%) in the nucleus (magnification, x200). (C) Negative expression of CD30 (magnification, x200). (D) Positive expression of p53 in the nucleus (magnification, x200). (E) High expression of Ki-67 ( $\geq 80 \%$ ) in the nucleus (magnification, x200). (F) Positive expression of CD30 in the cell membrane (magnification, x200). (G) Negative expression of Bcl-2 (magnification, x200). (H) Negative expression of c-Myc (magnification, x200). (I) Low expression of Bcl-2 (<70\%) in the cell membrane (magnification, x200). (J) Low expression of c-Myc $(<40 \%)($ magnification, $\mathrm{x} 200)$. (K) High expression of Bcl-2 $(\geq 70 \%)$ in the cell membrane (magnification, $x 200)$. (L) High expression of c-Myc ( $\geq 40 \%)$ in the nucleus (magnification, x200). MYD88, myeloid differentiation factor 88; Ki-67, proliferation marker protein Ki-67.

and 17.3 months, respectively. The 3- and 5-year OS rates were $15.79 \%$ (6/38) and 7.89\% (3/38), respectively.

Among patients with MYD88 L265P mutation, 16 passed away $(55.17 \%, 16 / 29)$ and 12 survived $(41.38 \%, 12 / 29)$. The median and average survival times were 9 and 17.5 months, respectively. The 3- and 5-year OS rates were $20.69 \%$ (6/29) and $7.89 \%$ (3/29), respectively.

Data analysis and statistics. Chi-square test analysis showed that positive MYD88 expression was significantly associated with sex (female; $\mathrm{P}=0.023$ ), extranodal site (CNS; $\mathrm{P}=0.031$ ), $\beta 2$-microglobulin ( $\beta 2$-MG; normal; $\mathrm{P}=0.039$ ), high expression of Bcl-2 ( $\geq 70 \%)$ and survival status (passed away; $\mathrm{P}=0.042$ ). MYD88 L265P mutation was significantly related to extranodal site (CNS; $\mathrm{P}<0.001$ ), $\beta 2-\mathrm{MG}$ (normal; $\mathrm{P}=0.004$ ), Ann-Arbor stage (stages III-IV; $\mathrm{P}=0.002$ ) and Eastern Cooperative Oncology Group performance status (ECOG PS) score ( $\geq 2$; $\mathrm{P}=0.001$ ) (Table I).

In univariate analysis, age ( $\geq 60$ years), high levels of lactic acid dehydrogenase (LDH), low lymphocyte count, rituximab treatment, high Bcl-2 expression ( $\geq 70 \%$ ), MYD88 expression and
MYD88 L265P mutation were significant prognostic factors for OS. In multivariate analysis, when NCCN-IPI was controlled, MYD88 positive expression [HR, 1.855, 95\% confidence interval (CI), 0.991-3.470], age $\geq 60$ years (HR, $1.982,95 \%$ CI, 1.065-3.688), high NLR (HR, 0.518, 95\% CI, 0.2276-0.969) were the independent prognostic factors affecting the OS of patients $(\mathrm{P}<0.05)$. However, MYD88 L265P mutation was not an independent prognostic factor of OS $(\mathrm{P}=0.07)$ (Table IV; Fig. 5A-G).

As for the crossing of survival curves in univariate analysis, landmark analysis was performed according to a landmark point at 4 months for MYD88 expression and 5 months for lymphocyte count, with the statistical differences in survival rates calculated separately for events that occurred up to landmark point time after randomization, events that occurred between landmark point time and the end of the follow-up period (Fig. 6).

\section{Discussion}

In the present study, expression of MYD88 in DLBCL was investigated using IHC and DDPCR. IHC was used to detect 
Table I. Correlation of MYD88 mutation and MYD88 expression with clinicopathological characteristics.

\begin{tabular}{|c|c|c|c|c|c|c|c|c|}
\hline \multirow[b]{2}{*}{$\begin{array}{l}\text { Clinicopathological } \\
\text { characteristics }\end{array}$} & \multicolumn{2}{|c|}{ MYD88 mutation } & \multirow[b]{2}{*}{$\chi^{2}$} & \multirow[b]{2}{*}{ P-value } & \multicolumn{2}{|c|}{ MYD88 expression } & \multirow[b]{2}{*}{$\chi^{2}$} & \multirow[b]{2}{*}{ P-value } \\
\hline & $\begin{array}{c}\text { WT } \\
(n=71)\end{array}$ & $\begin{array}{l}\text { MUT } \\
(n=29)\end{array}$ & & & $\begin{array}{l}\text { Negative } \\
(n=62)\end{array}$ & $\begin{array}{l}\text { Positive } \\
(\mathrm{n}=38)\end{array}$ & & \\
\hline \multicolumn{9}{|l|}{ Age $(n=100)$} \\
\hline$<60$ & 40 & 17 & 0.044 & 0.834 & 36 & 21 & 0.075 & 0.784 \\
\hline$\geq 60$ & 31 & 12 & & & 26 & 17 & & \\
\hline \multicolumn{9}{|l|}{$\operatorname{Sex}(n=100)$} \\
\hline Male & 44 & 15 & 0.894 & 0.344 & 42 & 17 & 5.155 & $0.023^{\mathrm{a}}$ \\
\hline Female & 27 & 14 & & & 20 & 21 & & \\
\hline \multicolumn{9}{|l|}{ Location $(n=100)$} \\
\hline Nodal & 31 & 6 & 4.661 & $0.031^{\mathrm{a}}$ & 25 & 12 & 0.773 & 0.379 \\
\hline Extranodal & 40 & 23 & & & 37 & 26 & & \\
\hline \multicolumn{9}{|l|}{ Extranodal involvement $(\mathrm{n}=63)$} \\
\hline CNS & 8 & 16 & 15.213 & $0^{\mathrm{a}}$ & 10 & 14 & 4.657 & $0.031^{\mathrm{a}}$ \\
\hline $\begin{array}{l}\text { Other (centrum, testis, soft tissue, } \\
\text { skin, spleen, breast) }\end{array}$ & 32 & 7 & & & 27 & 12 & & \\
\hline \multicolumn{9}{|l|}{ Hans' algorithm $(n=100)$} \\
\hline GCB & 28 & 8 & 1.255 & 0.263 & 26 & 10 & 2.495 & 0.114 \\
\hline $\mathrm{ABC}$ & 43 & 21 & & & 36 & 28 & & \\
\hline \multicolumn{9}{|l|}{ Ann-Arbor stage $(n=100)$} \\
\hline Low (I-II) & 23 & 1 & 9.458 & $0.002^{\mathrm{a}}$ & 14 & 10 & 2.495 & 0.671 \\
\hline High (III-IV) & 48 & 28 & & & 48 & 28 & & \\
\hline \multicolumn{9}{|l|}{$\beta 2-\mathrm{MB}(\mathrm{n}=55)$} \\
\hline Normal & 9 & 9 & 8.496 & $0.004^{\mathrm{a}}$ & 8 & 10 & 0.278 & $0.039^{\mathrm{a}}$ \\
\hline Above normal & 32 & 5 & & & 27 & 10 & & \\
\hline \multicolumn{9}{|l|}{ B symptom $(n=100)$} \\
\hline Absent & 55 & 27 & 3.412 & 0.065 & 51 & 31 & 0.007 & 0.932 \\
\hline Present & 16 & 2 & & & 11 & 7 & & \\
\hline \multicolumn{9}{|c|}{ ECOG performance status score $(n=100)$} \\
\hline$<2$ & 45 & 8 & 10.59 & $0.001^{\mathrm{a}}$ & 34 & 19 & 0.221 & 0.638 \\
\hline$\geq 2$ & 26 & 21 & & & 28 & 19 & & \\
\hline \multicolumn{9}{|l|}{ LDH level (n=99) } \\
\hline Normal & 46 & 20 & 0.398 & 0.528 & 41 & 25 & 0.022 & 0.883 \\
\hline Above normal & 25 & 8 & & & 21 & 12 & & \\
\hline \multicolumn{9}{|l|}{ NCCN-IPI (n=100) } \\
\hline Low risk (0-1) & 7 & 2 & 12.099 & 0.07 & 6 & 3 & 2.271 & 0.518 \\
\hline Low intermediate risk (2-3) & 47 & 10 & & & 36 & 21 & & \\
\hline High intermediate risk (4-5) & 15 & 13 & & & 18 & 10 & & \\
\hline High risk $(\geq 6)$ & 2 & 4 & & & 2 & 4 & & \\
\hline \multicolumn{9}{|l|}{ Survival status $(n=100)$} \\
\hline Died & 29 & 16 & 1.743 & 0.418 & 23 & 22 & 6.348 & $0.042^{\mathrm{a}}$ \\
\hline Alive & 38 & 12 & & & 37 & 13 & & \\
\hline Status unknown & 4 & 1 & & & 2 & 3 & & \\
\hline \multicolumn{9}{|l|}{ Progression-free survival $(n=69)$} \\
\hline 3 & 3 & 3 & 1.807 & 0.166 & 2 & 4 & 0.484 & 0.487 \\
\hline 5 & 0 & 1 & 1.064 & 0.144 & 0 & 1 & 1.234 & 0.267 \\
\hline \multicolumn{9}{|l|}{ Overall survival $(n=95)$} \\
\hline 3 & 21 & 6 & 1.807 & 0.179 & 21 & 6 & 4.772 & $0.029^{\mathrm{a}}$ \\
\hline 5 & 13 & 3 & 1.064 & 0.302 & 13 & 3 & 2.107 & 0.1 \\
\hline
\end{tabular}

MYD88, myeloid differentiation factor 88; WT, wild-type; MUT, mutant; CNS, central nervous system; GCB, germinal center B cell like; ABC, activated B cell like; ECOG, Eastern Cooperative Oncology Group; LDH, lactic acid dehydrogenase; NCCN-IPI, NCCN International Prognostic Index; $\beta 2-\mathrm{MG}, \beta 2$-microglobulin. ${ }^{\mathrm{a}} \mathrm{P}<0.05$. 
Table II. Correlation between MYD88 and other IHC indicators.

\begin{tabular}{|c|c|c|c|c|c|c|c|c|}
\hline \multirow[b]{2}{*}{ Gene } & \multicolumn{2}{|c|}{ MYD88 mutation } & \multicolumn{2}{|c|}{ Chi-square test } & \multicolumn{2}{|c|}{ MYD88 expression } & \multicolumn{2}{|c|}{ Chi-square test } \\
\hline & WT $(n=71)$ & $\operatorname{MUT}(n=29)$ & $\chi^{2}$ & P-value & Negative $(n=62)$ & Positive $(\mathrm{n}=38)$ & $\chi^{2}$ & P-value \\
\hline \multicolumn{9}{|c|}{$\mathrm{CD} 10(\mathrm{n}=100)$} \\
\hline Positive & 18 & 6 & & & 17 & 7 & & \\
\hline Negative & 53 & 23 & 0.245 & 0.62 & 45 & 31 & 1.046 & 0.306 \\
\hline \multicolumn{9}{|c|}{$\operatorname{Bcl}-6(n=100)$} \\
\hline Positive & 63 & 21 & & & 54 & 30 & & \\
\hline Negative & 8 & 7 & 2.946 & 0.086 & 8 & 7 & 0.652 & 0.419 \\
\hline \multicolumn{9}{|c|}{ MUM-1 (n=99) } \\
\hline Positive & 55 & 25 & & & 47 & 33 & & \\
\hline Negative & 16 & 3 & 1.809 & 0.179 & 15 & 4 & 2.676 & 0.102 \\
\hline \multicolumn{9}{|c|}{$\mathrm{Bcl}-2(\mathrm{n}=98)$} \\
\hline$\geq 70 \%$ & 20 & 13 & & & 16 & 17 & & \\
\hline$<70 \%$ & 20 & 6 & 2.855 & 0.24 & 22 & 4 & 8.373 & $0.015^{\mathrm{a}}$ \\
\hline \multicolumn{9}{|c|}{ Myc (n=94) } \\
\hline$\geq 40 \%$ & 26 & 8 & & & 22 & 12 & & \\
\hline$<40 \%$ & 15 & 8 & 1.051 & 0.591 & 10 & 13 & 4.512 & 0.105 \\
\hline \multicolumn{9}{|c|}{$\begin{array}{l}\mathrm{Myc}(\geq 40 \%) \text { and Bcl-2 } \\
(\geq 70 \%) \text { DE }(\mathrm{n}=94)\end{array}$} \\
\hline Positive & 10 & 2 & & & 8 & 4 & & \\
\hline Negative & 61 & 27 & 1.007 & 0.316 & 54 & 34 & 0.126 & 0.723 \\
\hline \multicolumn{9}{|c|}{$\operatorname{CD} 30(n=100)$} \\
\hline Positive & 7 & 2 & & & 7 & 2 & & \\
\hline Negative & 64 & 27 & 0.221 & 0.639 & 55 & 36 & 1.045 & 0.307 \\
\hline \multicolumn{9}{|l|}{ p53 (n=91) } \\
\hline Positive & 39 & 14 & & & 32 & 21 & & \\
\hline Negative & 27 & 11 & 0.071 & 0.79 & 24 & 14 & 0.072 & 0.788 \\
\hline \multicolumn{9}{|c|}{ Ki-67 (n=100) } \\
\hline$\geq 60 \%$ & 60 & 24 & & & 57 & 27 & & \\
\hline$<60 \%$ & 11 & 5 & 0.047 & 0.829 & 5 & 11 & 7.645 & $0.006^{\mathrm{a}}$ \\
\hline \multicolumn{9}{|c|}{ MYD88 expression $(n=100)$} \\
\hline Positive & 18 & 20 & & & & & & \\
\hline Negative & 53 & 9 & 18.101 & $0^{\mathrm{a}}$ & & & & \\
\hline
\end{tabular}

MYD88, myeloid differentiation factor 88; WT, wild-type; MUT, mutant; MUM-1, myeloma-associated antigen-1; Ki-67, proliferation marker protein Ki-67; IHC, immunohistochemistry; DE, double expression. ${ }^{a} \mathrm{P}<0.05$.

protein expression of MYD88. Only a few studies have reported on using IHC to detect MYD88 protein expression. Choi et al (29) found that MYD88 was overexpressed in $38.7 \%$ (48/124) of DLBCL cases. This finding was consistent with the results of the present study (38\%). Furthermore, positive expression of MYD88 was correlated with sex, $\beta 2-\mathrm{MG}$ and survival status. The correlation with sex and $\beta 2-\mathrm{MG}$ has yet to be proposed, and the underlying mechanisms should be studied further. Notably, positive MYD88 expression was positively correlated with high expression of Bcl-2 in the present study, which could indicate that MYD88 and Bcl-2 inhibit tumor cell apoptosis, promote tumor cell proliferation, enhance the role of other oncogenes and induce lymphoma. Bcl-2 protein accelerates the growth of lymphoma and promotes the resistance of tumor cells to chemotherapy drugs $(31,32)$. Positive MYD88 expression was positively correlated with high Ki-67 expression. This finding suggested that MYD88 may inhibit tumor cell apoptosis and promote tumor proliferation.

Meanwhile, the mutation of MYD88 L265P was studied at a molecular level by DDPCR. Previous studies have provided evidence that the MYD88 L265P mutation is associated with a poor prognosis in patients with DLBCL who have been treated with standard R-CHOP immunochemotherapy $(19,33,34)$. These findings are in agreement with the present results. However, some studies have demonstrated that the mutation of MYD88 does not affect the OS rate of patients with lymphoma $(35,36)$. Therefore, this topic needs further investigation. In previous studies, the MYD88 L265P mutation was 

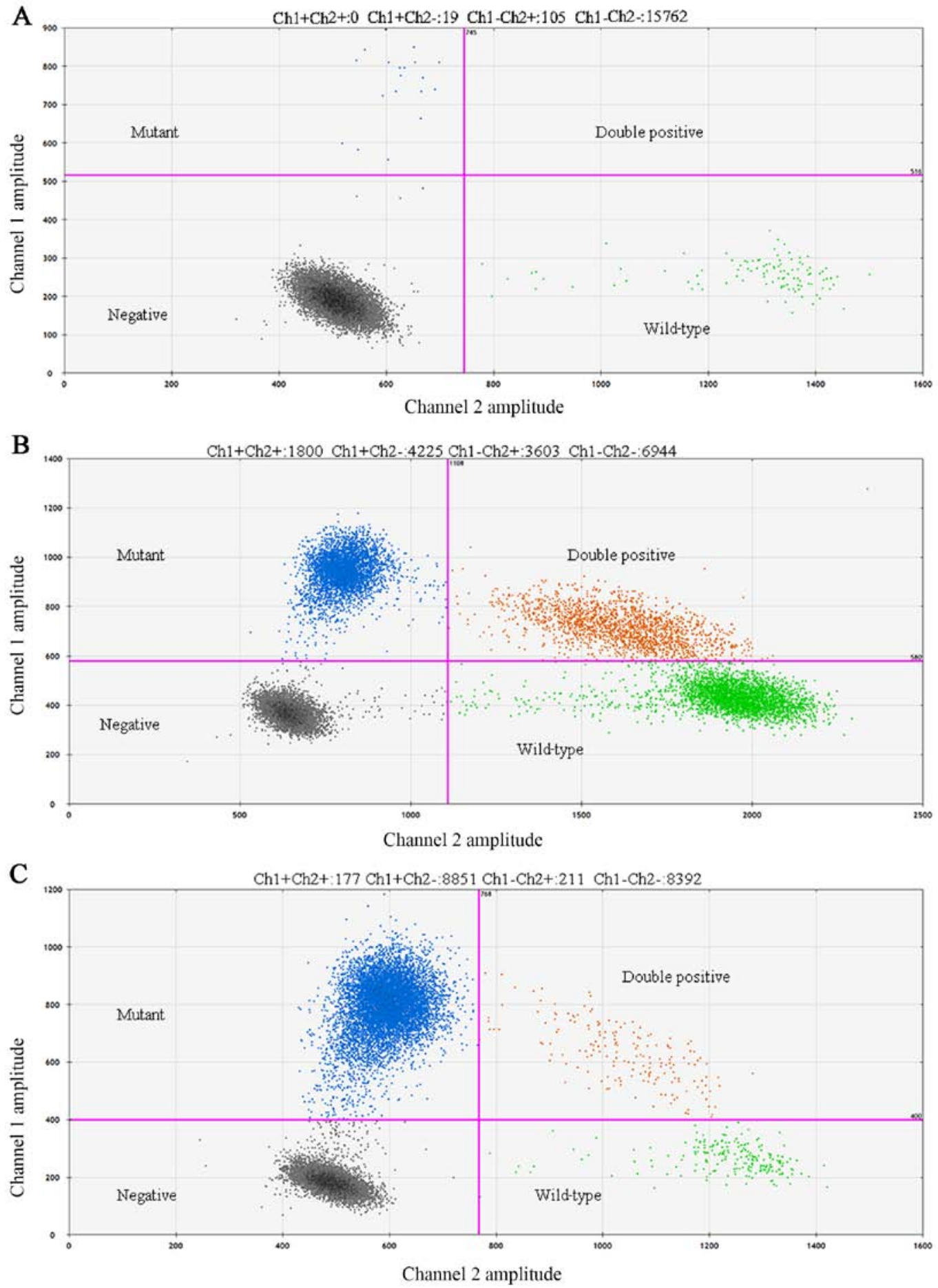

Figure 4. Droplet digital PCR of the diffuse large B cell lymphoma formaldehyde-fixed paraffin-embedded tissue showing presence of myeloid differentiation factor $88 \mathrm{~L} 265 \mathrm{P}$ mutant droplets (blue droplets, Ch1+/Ch2-). (A) Mutation frequency $<10 \%$; (B) mutation frequency $<50 \%$; (C) mutation frequency $\geq 50 \%$. Ch1, mutation copy number; Ch2, wild-type copy number; $\mathrm{Ch} 1+\mathrm{Ch} 2$, genomic DNA copy number; $\mathrm{Ch} 1 /(\mathrm{Ch} 1+\mathrm{Ch} 2)$, mutation frequency. Green droplets depict wild-type droplets (Ch1-/Ch2+) region; gray droplets depict negative droplets without detectable DNA (Ch1-/Ch2-) region; orange droplets depict double positive droplets (Ch1+/Ch2+) region. Result judgment: i) Positive, mutation frequency $\geq 1 \%$ and $\geq 3$ droplets fall in the 'Ch1+Ch2-' region; ii) Negative, $<3$ droplets fall in the 'Ch1+' region and $<5$ droplets fall in the ' $\mathrm{Ch} 2+$ ' region.

found in $6.5-19 \%$ of DLBCL cases $(12,19,29)$. In the present study, the MYD88 L265P mutation was found in 29\% of patients with DLBCL. This mutation was also positively correlated with the ECOG score; patients with a higher score had a higher mutation rate compared with those with a lower score (72.4 vs. $27.6 \%)$. An ECOG score is an index used to understand the general health status, tolerance to treatment and physical status of patients. Lee et al (37) performed a meta-analysis on the MYD88 L265P gene mutation in lymphoma and found that MYD88 L265P mutation is related to age, prognosis and immunophenotyping, but it is not related to clinical stage and sex. The present results revealed that this gene mutation is associated with Ann-Arbor staging, which may be associated with a large proportion of PCNSL, 

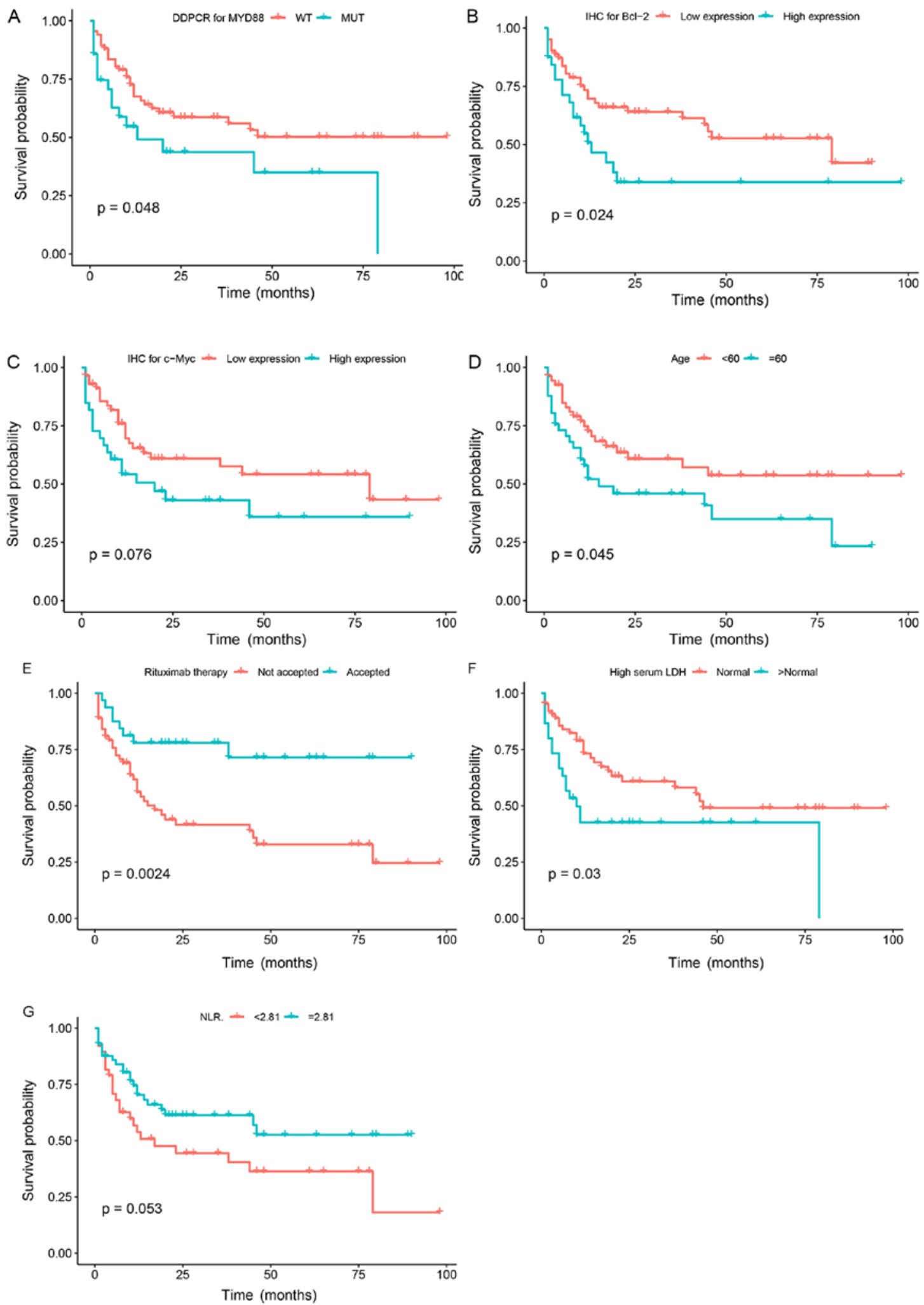

Figure 5. Mutation status and Kaplan-Meier survival curves of patients with diffuse large B cell lymphoma (n=100 patients). (A) Kaplan-Meier analysis of overall survival according to MYD88 mutation status among all patients. (B) Kaplan-Meier analysis of overall survival according to Bcl-2 expression status among all patients. (C) Kaplan-Meier analysis of overall survival according to c-Myc expression status among all patients. (D) Kaplan-Meier analysis of overall survival according to age status among all patients. (E) Kaplan-Meier analysis of overall survival according to Rituximab therapy status among all patients. (F) Kaplan-Meier analysis of overall survival according to LDH level status among all patients. (G) Kaplan-Meier analysis of overall survival according to NLR status among all patients. MYD88, myeloid differentiation factor 88; DDPCR, droplet digital PCR; WT, wild-type; MUT, mutant; IHC, immunohistochemistry; LDH, lactic acid dehydrogenase; NLR, neutrophil/lymphocyte count ratio.

thereby increasing the mutation rate of patients in stages III-IV.
In the current study, the MYD88 L265P mutation was found to be common in extranodal DLBCL, including the CNS 
A

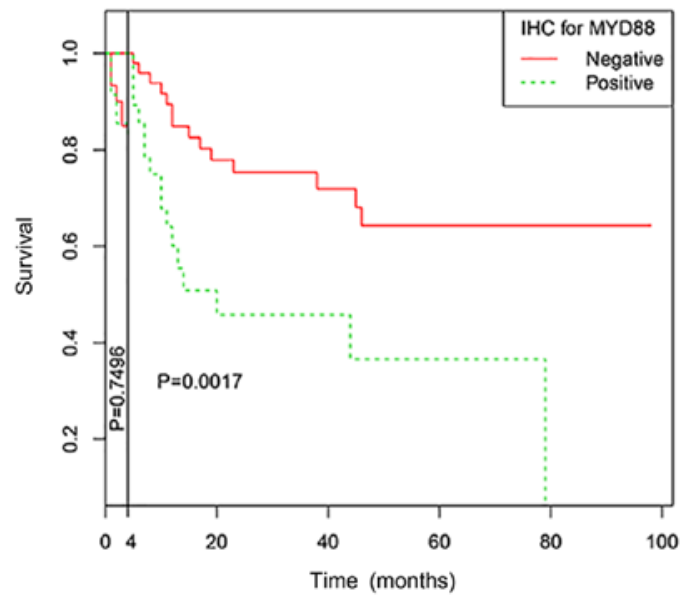

B

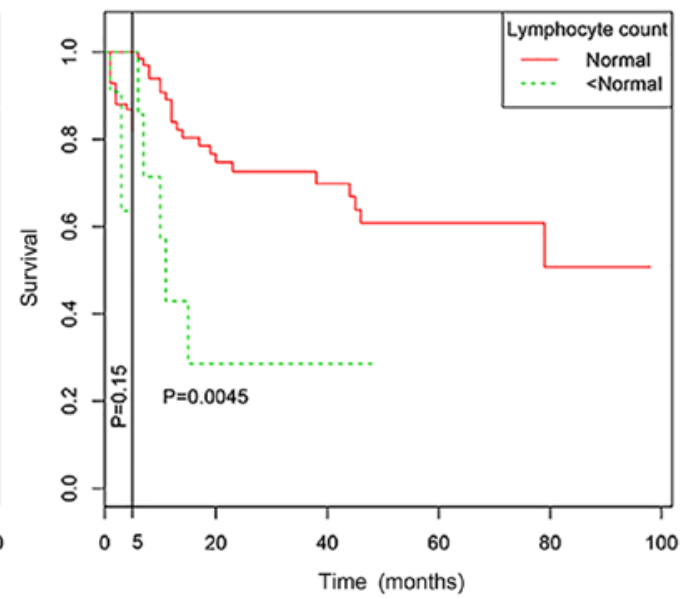

Figure 6. Landmark analysis of patients with diffuse large B cell lymphoma ( $\mathrm{n=100}$ patients). (A) Landmark analysis of overall survival according to MYD88 expression status among all patients. (B) Landmark analysis of overall survival according to lymphocyte count status among all patients. MYD88, myeloid differentiation factor 88 ; IHC, immunohistochemistry.

and testes, and associated with poor prognosis. However, the MYD88 L265P mutation was not an independent prognostic factor of $\mathrm{OS}(\mathrm{P}=0.07)$. The survival time of the elderly patients was shorter $(\mathrm{P}<0.05)$, which might be related to a decrease in immune system function and tolerance to chemotherapeutic drugs. Patients might also be affected by primary diseases other than lymphoma. By comparison, patients with PCNSL were more likely to present advanced-stage diseases and were associated with a lower average survival (17.4 months) compared with patients with nodal DLBCL (23.8 months). This observation might be related to the special growth site of the tumor. Tumors occurring in the brain are affected by the blood-brain barrier, which could decrease the efficacy of chemotherapy. Patients with high LDH levels had poor prognosis rates, which might be related to the metabolism of tumor cells in patients with lymphoma. The enhanced glycolysis and necrotic tumor tissues in patients with lymphoma can increase serum LDH levels. LDH levels can also be used as an independent prognostic factor of various tumors, such as breast cancer and renal cell carcinoma $(38,39)$. The effect of NCCN-IPI score on the survival time of patients indicates that the prognosis of patients with a high score is poor (40). The relationship between indicators in the blood and prognosis of pre-treated patients with DLBCL were analyzed. Patients with low and high lymphocyte counts had a poorer prognosis, possibly because lymphocytes also play an important role in antitumor immunity. Given the lack of sufficient antitumor immunity, lymphocyte downregulation can promote tumor recurrence and metastasis (41). High NLR was found to be an independent prognostic factor affecting the OS of patients. Previous studies demonstrated that high NLR is related to an increase in monocyte chemoattractant protein-1, IL-1R- $\alpha$, IL-6, IL-7, IL-8, IL-12 and IL-17 in the peripheral blood $(42,43)$. These cytokines can establish and maintain an immune microenvironment that promotes tumor invasion. The poor prognosis of DLBCL caused by high NLR may be related to the immune microenvironment. In the present study, the expression and mutation of MYD88 were not significantly correlated with PFS. These findings might be due to the number of patients who could be followed up. MYD88 has a high mutation rate at protein and molecular levels in ABC-DLBCL and PCNSL, and the mutation rate is high in ABC-DLBCL with poor prognosis (44). This result might be related to the key role of MYD88 protein in the NF- $\kappa \mathrm{B}$ pathway, overexpression can lead to the aberrant activation of this pathway $(12,45,46)$, although the activation of the $\mathrm{NF}-\kappa \mathrm{B}$ pathway maintains the activity of ABC-DLBCL cells it is unable to maintain the activity of GCB-DLBCL cells (47). The MYD88 mutation in patients with ABC-DLBCL and PCNSL is of great significance to evaluate the prognosis of DLBCL, suggesting that this is a potential therapeutic target with immunotherapies. It has previously been reported that the MYD88 mutation rate of primary testicular diffuse large B cell lymphoma (PT-DLBCL) is $68 \%$, and associated with a poor survival $(21,48,49)$. Mutations were detected in three patients with PT-DLBCL (2/3) in the present study. During the follow-up of these three patients, one patient with the mutation passed away and the other gave up treatment, and the wild-type patient survived until the end of the follow-up. As the sample size used for PT-DLBCL was small, specific conclusions about this finding cannot be made. The mutation rate of MYD88 in PCNSL was $66.67 \%(16 / 24)$. A positive correlation was observed between them, but the mutation did not affect OS and PFS in patients. Studies have reported that MYD88 L265P mutation occurs in PCNSL with poor prognosis $(50,51)$. The present study also included one patient with primary cutaneous DLBCL-LT, which was detected as the MYD88 wild-type. DLBCL-LT was the most aggressive primary cutaneous B cell lymphoma subtype and was associated with an increased risk of extracutaneous spread and poor prognosis. In previous studies, the MYD88 mutation rate of DLBCL-LT is reported to be $59 \%$, and prognosis is poor $(20,52)$.

Our group has recorded 1,831 lymphoma cases in our department over the past 10 years, and it was found that the incidence of DLBCL was as high as $57 \%(741 / 1,294)$ in B cell lymphoma (Fig. S2A and B). This is consistent with the findings of $\mathrm{Li}$ et al (53) who revealed that the incidence of DLBCL is $50.18 \%(3,328 / 6,632)$. 
Table III. Clinical characteristics and follow-up of patients with diffuse large B cell lymphoma with MYD88 L265P mutation.

\begin{tabular}{|c|c|c|c|c|c|c|c|c|c|}
\hline Case & $\begin{array}{l}\text { Age } \\
\text { (year) }\end{array}$ & $\begin{array}{c}\text { Primary } \\
\text { site }\end{array}$ & Stage & Subtype & $\begin{array}{c}\text { Initial } \\
\text { treatment }\end{array}$ & $\begin{array}{c}\text { Survival } \\
\text { status }\end{array}$ & $\begin{array}{c}\text { Follow up } \\
\text { (months) }\end{array}$ & DDPCR & IHC \\
\hline 1 & 75 & Joint & IA & $\mathrm{ABC}$ & CHOP & Passed away & 79 & $31.3 \%$ L265P Mut & Positive \\
\hline 2 & 60 & CNS & IVA & $\mathrm{ABC}$ & $\mathrm{R}-\mathrm{CHOP}+\mathrm{MTX}$ & Alive & 63 & $35.8 \%$ L265P Mut & Negative \\
\hline 3 & 46 & $\mathrm{LN}$ & IVB & $\mathrm{ABC}$ & $\mathrm{R}-\mathrm{CHOP}+\mathrm{PBSCT}$ & Alive & 61 & $0.14 \%$ L265P Mut & Positive \\
\hline 4 & 69 & Testis & IIIA & $\mathrm{ABC}$ & Surgery & Passed away & 46 & $45.1 \%$ L265P Mut & Positive \\
\hline 5 & 60 & Joint & IVA & GCB & Surgery & Alive & 51 & $14.0 \%$ L265P Mut & Positive \\
\hline 6 & 66 & $\mathrm{LN}$ & IVA & $\mathrm{ABC}$ & Unknown & Unknown & & $55.0 \%$ L265P Mut & Positive \\
\hline 7 & 82 & $\mathrm{LN}$ & IVA & $\mathrm{ABC}$ & MTX & Passed away & 1 & 69.1\% L265P Mut & Positive \\
\hline 8 & 59 & $\begin{array}{l}\text { Head and } \\
\text { neck }\end{array}$ & IVA & $\mathrm{ABC}$ & R-CHOP & Alive & 48 & $22.9 \%$ L265P Mut & Negative \\
\hline 9 & 65 & CNS & IVA & GCB & Unknown & Passed away & 2 & $42.8 \%$ L265P Mut & Negative \\
\hline 10 & 50 & CNS & IVA & $\mathrm{ABC}$ & Unknown & Passed away & 1 & $74.8 \%$ L265P Mut & Positive \\
\hline 11 & 51 & CNS & IVA & $\mathrm{ABC}$ & Unknown & Passed away & 20 & $25.0 \%$ L265P Mut & Positive \\
\hline 12 & 72 & CNS & IVA & $\mathrm{ABC}$ & Unknown & Passed away & 1 & $50.9 \%$ L265P Mut & Positive \\
\hline 13 & 46 & CNS & IVA & $\mathrm{ABC}$ & $\mathrm{R}-\mathrm{CHOP}+\mathrm{MTX}$ & Alive & 26 & 96.6\% L265P Mut & Positive \\
\hline 14 & 75 & $\mathrm{LN}$ & IIIA & $\mathrm{ABC}$ & Surgery & Passed away & 1 & $44.7 \%$ L265P Mut & Negative \\
\hline 15 & 40 & CNS & IVA & $\mathrm{ABC}$ & Unknown & Alive & 22 & $0.31 \%$ L265P Mut & Positive \\
\hline 16 & 53 & CNS & IVA & $\mathrm{ABC}$ & MTX + TMZ & Passed away & 8 & $44.3 \%$ L265P Mut & Positive \\
\hline 17 & 60 & $\begin{array}{l}\text { Head and } \\
\text { neck }\end{array}$ & IVA & GCB & R-CHOP & $\mathrm{CR}$ & 21 & $35.7 \%$ L265P Mut & Positive \\
\hline 18 & 50 & $\mathrm{LN}$ & IIIB & $\mathrm{ABC}$ & Unknown & Passed away & 13 & $0.16 \%$ L265P Mut & Positive \\
\hline 19 & 64 & $\mathrm{LN}$ & IVA & $\mathrm{ABC}$ & Unknown & Passed away & 2 & $83.7 \%$ L265P Mut & Negative \\
\hline 20 & 55 & CNS & IVA & GCB & $\mathrm{R}-\mathrm{CHOP}+\mathrm{MTX}$ & Passed away & 5 & $95.8 \%$ L265P Mut & Positive \\
\hline 21 & 72 & CNS & IVA & $\mathrm{ABC}$ & MTX & Passed away & 10 & 45.7\% L265P Mut & Positive \\
\hline 22 & 53 & CNS & IVA & $\mathrm{ABC}$ & Surgery & Alive & 12 & $38.8 \%$ L265P Mut & Positive \\
\hline 23 & 54 & CNS & IVA & GCB & Surgery & Alive & 8 & $32.7 \%$ L265P Mut & Negative \\
\hline 24 & 61 & CNS & IVA & GCB & Surgery & Alive & 3 & $58.3 \%$ L265P Mut & Negative \\
\hline 25 & 59 & CNS & IVA & $\mathrm{ABC}$ & Surgery & Alive & 1 & $25.2 \%$ L265P Mut & Positive \\
\hline 26 & 59 & CNS & IVA & $\mathrm{ABC}$ & Surgery & Passed away & 45 & 96.99\% L265P Mut & Negative \\
\hline 27 & 64 & CNS & IVA & GCB & $\begin{array}{l}\text { R-CHOP + } \\
\text { MTX + TMZ }\end{array}$ & Passed away & 2 & $53.4 \%$ L265P Mut & Positive \\
\hline 28 & 54 & Joint & IVA & GCB & Unknown & Passed away & 6 & $52.7 \%$ L265P Mut & Negative \\
\hline 29 & 69 & Testis & IVA & $\mathrm{ABC}$ & Unknown & Alive & 12 & $42.8 \%$ L265P Mut & Positive \\
\hline
\end{tabular}

LN, lymph node; CNS, central nervous system; CHOP, cyclophosphamide, doxorubicin, vincristine and prednisone; R-CHOP, rituximab, cyclophosphamide, doxorubicin, vincristine and prednisone; PBSCT, peripheral blood stem cell transplantation; MTX, methotrexate; TMZ, temozolomide; GCB, germinal center B cell like; ABC, activated B cell like; Mut, mutant; IHC, immunohistochemistry; DDPCR, droplet digital polymerase chain reaction; MYD88, myeloid differentiation factor 88.

These results indicated that MYD88 protein is highly expressed in PCNSL, which could be observed easily, especially in tumor cells around blood vessels. Our data would support that the hypothesis that MYD88 had a function of labeling tumor cells. However, when MYD88 protein expression in DLBCL occurred in lymph nodes, some problems, such as non-specific background coloring and false positive in some cases, were encountered.

Different techniques, such as Sanger sequencing and allele-specific quantitative PCR, have been used to detect MYD88 mutations in lymphoma (23). However, these methods require large samples and cannot be used as routine detection methods. DDPCR is a highly sensitive gene mutation detection technique with a low DNA requirement. DDPCR is a valuable method in current diagnostic parameters, especially when the available amount of DNA is limited. It is suitable for screening bone marrow, peripheral blood cells, circulating free DNA and minimal residual disease $(54,55)$. It is also a highly reliable method that can be applied to detect MYD88 gene mutations in cerebrospinal fluid even when the DNA input is low (56). To the best of the authors' knowledge, this is the first time that the DDPCR technique has been applied to detect a MYD88 mutation in DLBCL FFPE tumor tissues and been used to compare the results with IHC data. The coincidence rate of the results of MYD88 expression between IHC and DDPCR results was $73 \%$ (73/100). However, statistical analysis showed that the 
Table IV. Clinicopathological characteristics affecting PFS and OS.

\begin{tabular}{|c|c|c|c|c|c|c|}
\hline \multirow[b]{2}{*}{ Clinicopathological characteristics } & \multicolumn{2}{|c|}{ Univariate analysis } & \multicolumn{4}{|c|}{ Multivariate analysis } \\
\hline & $\begin{array}{c}\text { PFS } \\
\text { P-value }\end{array}$ & $\begin{array}{c}\text { OS } \\
\text { P-value }\end{array}$ & $\begin{array}{c}\text { PFS } \\
\text { HR }(95 \% \mathrm{CI})\end{array}$ & $\begin{array}{c}\text { OS } \\
\text { P-value }\end{array}$ & $\operatorname{HR}(95 \% \mathrm{CI})$ & P-value \\
\hline \multicolumn{7}{|l|}{ Age } \\
\hline$<60$ vs. $\geq 60$ & 0.286 & $0.045^{\mathrm{a}}$ & & & $1.982(1.065-3.688)$ & $0.031^{\mathrm{a}}$ \\
\hline \multicolumn{7}{|l|}{$\operatorname{Sex}(n=100)$} \\
\hline Male vs. female & 0.452 & 0.393 & & & & \\
\hline \multicolumn{7}{|l|}{ Extranodal involvement } \\
\hline CNS vs. other & 0.535 & 0.146 & & & & \\
\hline \multicolumn{7}{|l|}{ Ann-Arbor stage } \\
\hline Low (I-II) vs. high (III-IV) & 0.899 & 0.621 & & & & \\
\hline \multicolumn{7}{|l|}{$\beta 2-\mathrm{MB}(\mathrm{n}=55)$} \\
\hline Normal vs. above normal & 0.732 & 0.981 & & & & \\
\hline \multicolumn{7}{|l|}{ B symptom $(n=100)$} \\
\hline Absent vs. present & 0.359 & 0.872 & & & & \\
\hline \multicolumn{7}{|l|}{ ECOG performance status $(n=100)$} \\
\hline$<2$ vs. $\geq 2$ & 0.267 & 0.526 & & & & \\
\hline \multicolumn{7}{|l|}{ LDH level $(n=99)$} \\
\hline Normal vs. above normal & 0.883 & $0.03^{\mathrm{a}}$ & & & & 0.241 \\
\hline \multicolumn{7}{|l|}{ Ann-Arbor stage } \\
\hline GCB vs. ABC & 0.5 & 0.763 & & & & 0.625 \\
\hline \multicolumn{7}{|l|}{ Therapy $(\mathrm{n}=53)$} \\
\hline Rituximab & 0.299 & $0.002^{\mathrm{a}}$ & & & & \\
\hline \multicolumn{7}{|l|}{ Others } \\
\hline \multicolumn{7}{|l|}{ IHC } \\
\hline Bcl-6 $(n=100)$ & 0.365 & 0.541 & & & & \\
\hline Bcl $-2 \geq 70$ vs. $<70 \%(\mathrm{n}=98)$ & 0.576 & $0.024^{\mathrm{a}}$ & & & & 0.218 \\
\hline c-Myc $\geq 40$ vs. $<40 \%(n=94)$ & 0.782 & 0.076 & & & & \\
\hline c-Myc $(\geq 40 \%) /$ BCL-2 $(\geq 70 \%)$ co-expression $(n=94)$ & 0.707 & 0.64 & & & & \\
\hline p53 (n=91) & 0.685 & 0.618 & & & & \\
\hline Ki-67 ( $\geq 60$ vs. $<60 \%(n=100)$ & 0.169 & 0.914 & & & & \\
\hline MYD88 positive vs. negative expression $(n=100)$ & 0.796 & $0.0017^{\mathrm{a}}$ & & & $1.855(0.991-3.470)$ & $0.05^{\mathrm{a}}$ \\
\hline MYD88 MUT vs. WT (n=100) & 0.624 & $0.048^{\mathrm{a}}$ & & & & 0.308 \\
\hline \multicolumn{7}{|l|}{ Hematologic indicators $(n=100)$} \\
\hline Monocyte count (normal vs. low vs. high) & 0.274 & 0.454 & & & & \\
\hline Neutrophil count (normal vs. low vs. high) & 0.237 & 0.399 & & & & \\
\hline Lymphocyte count (normal vs. $<$ normal & 0.145 & $0.0045^{\mathrm{a}}$ & & & & 0.109 \\
\hline Platelet count (normal vs. low vs. high) & 0.811 & 0.276 & & & & \\
\hline Hemoglobin (normal vs. low) & 0.668 & 0.68 & & & & \\
\hline High-NLR ( $\geq 2.81)$ vs. low-NLR $(<2.81)$ & 0.776 & 0.053 & & & $0.518(0.2276-0.969)$ & $0.04^{\mathrm{a}}$ \\
\hline High-LMR $(\geq 2.71)$ vs. low-LMR $(<2.71)$ & 0.280 & 0.083 & & & & \\
\hline
\end{tabular}

PFS, progression-free survival; OS, overall survival; HR, hazard ratio; CI, confidence interval; CNS, central nervous system; GCB, germinal center B cell like; ABC, activated B cell like; ECOG, Eastern Cooperative Oncology Group; LDH, lactic acid dehydrogenase; IHC, immunohistochemistry; MUM-1, melanoma ubiquitous mutated protein; Ki-67, proliferation marker protein Ki-67; MYD88, myeloid differentiation factor 88; MUT, mutant; WT, wild-type; NLR, neutrophil/lymphocyte count ratio; LMR, lymphocyte/monocyte count ratio; $\beta 2-\mathrm{MG}, \beta 2$-microglobulin. ${ }^{\mathrm{a}} \mathrm{P}<0.05$.

protein expression of MYD88 was positively correlated with the MYD88 L265P mutation, suggesting that using IHC to detect MYD88 expression could also be used as a preliminary screening method for lymphoma. 
In conclusion, IHC and DDPCR were performed to study the protein expression and mutation rates of MYD88 in DLBCL. These analyses revealed that the expression and mutation rates of MYD88 were higher in ABC-DLBCL compared with those of GCB-DLBCL. The expression of MYD88 protein was related to the high expression of $\mathrm{Bcl}-2$ and $\mathrm{Ki}-67$, indicating that MYD88 was related to tumor proliferation. MYD88 mutation was associated with $\beta 2-\mathrm{MG}$, Ann-Arbor staging and ECOG PS score. The expression and mutation of MYD88 protein were related to OS but not to PFS. The poor prognosis of patients with DLBCL was related to age, LDH level, lymphocyte count, NLR, treatment with rituximab and high Bcl-2 expression. MYD88 was associated with shortened survival, and might ultimately provide the molecular tools for immunotherapy assessment, and identify the patients at an increased risk of associated DLBCL events. The main limitation of the present study is that it was conducted at a single center so the sample was too small to reach firm conclusions. Therefore, further verification is needed in a larger sample.

\section{Acknowledgements}

Not applicable.

\section{Funding}

This work was supported by the project of National Natural Science Foundation of China (grant no. 81660036).

\section{Availability of data and materials}

The datasets used and/or analyzed during the current study are available from the corresponding author on reasonable request.

\section{Authors' contributions}

JN, XL and ZM conceived and designed the study; SL, AN and GA performed the experiments; WC, HG and LSJ analyzed the data; WZ and ZM interpreted the data. JN wrote the manuscript; JN, XL and WZ gave final approval of the version to be published. All authors read and approved the manuscript.

\section{Ethics approval and consent to participate}

The study protocol was approved by the Ethics Review Board of The First Affiliated Hospital of Xinjiang Medical University (approval no. 20160218-13). Written informed consent was obtained from all participants. All of the procedures were performed in accordance with the Declaration of Helsinki and relevant policies in China.

\section{Patient consent for publication}

Not applicable.

\section{Competing interests}

The authors declare that they have no competing interests.

\section{References}

1. Swerdlow SH, Campo E, Harris NL, Jaffe ES, Pileri SA, Stein H and Thiele J (eds): WHO Classification of tumours of haematopoietic and lymphoid tissues. 4th Edition. International Agency for Research on Cancer, Lyon, 2017.

2. Li XQ, Li GD, Gao ZF, Zhou XG and Zhu XZ: Distribution pattern of lymphoma subtypes in China: A nationwide multicenter study of 10002 cases. Zhen Duan Xue Li Lun Yu Shi Jian Bian Ji Bu: 25-29, 2012.

3. Al-Hamadani M, Habermann TM, Cerhan JR, Macon WR, Maurer MJ and Go RS: Non-Hodgkin lymphoma subtype distribution, geodemographic patterns, and survival in the US: A longitudinal analysis of the National Cancer Data Base from 1998 to 2011. Am J Hematol 90: 790-795, 2015.

4. Szumeraciećkiewicz A, Gałązka K, Szpor J, Rymkiewicz G, Jesionek-Kupnicka D, Gruchała A, Ziarkiewicz-Wróblewska B, Poniatowska-Broniek G, Demczuk S, Prochorec-Sobieszek M: Distribution of lymphomas in Poland according to World Health Organization classification: Analysis of 11718 cases from National Histopathological Lymphoma Register project - the Polish Lymphoma Research Group study. Int J Clin Exp Pathol 7: 32803286, 2014.

5. Wright G, Tan B, Rosenwald A, Hurt EH, Wiestner A and Staudt LM: A gene expression-based method to diagnose clinically distinct subgroups of diffuse large B cell lymphoma. Proc Natl Acad Sci USA 100: 9991-9996, 2003.

6. Alizadeh AA, Eisen MB, Davis RE, Ma C, Lossos IS, Rosenwald A Boldrick JC, Sabet H, Tran T, Yu X, et al: Distinct types of diffuse large B-cell lymphoma identified by gene expression profiling. Nature 403: 503-511, 2000.

7. Rubenstein JL, Gupta NK, Mannis GN, Lamarre AK and Treseler P: How I treat CNS lymphomas. Blood 122: 2318-2330, 2013.

8. Johnson S, Feldman M and Krishnamurthi V: Primary testicular lymphoma. J Urol 193: 315-316, 2015.

9. Horne MJ and Adeniran AJ: Primary diffuse large B-cell lymphoma of the testis. Arch Pathol Lab Med 135: 1363-1367, 2011.

10. Yanga LI,Liu ZG and Hao LC: Effectiveness and safety of rituximab plus CHOP chemotherapy for treating non-Hodgkin lymphoma among Chinese people: A meta-analysis. J Evid Based Med 11: 112-116, 2011.

11. Van Den NesteE, Schmitz N, Mounier N, Gill D, Linch D, Trneny M, Bouadballah R, Radford J, Bargetzi M, Ribrag V, et al: Outcomes of diffuse large B-cell lymphoma patients relapsing after autologous stem cell transplantation: An analysis of patients included in the CORAL study. Bone Marrow Transplant 52: 216-221, 2017.

12. Ngo VN, Young RM, Schmitz R, Jhavar S, Xiao W, Lim KH, Kohlhammer H, Xu W, Yang Y, Zhao H, et al: Oncogenically active MYD88 mutations in human lymphoma. Nature 470: 115-119, 2011.

13. O'Neill LA, Fitzgerald KA and Bowie AG: The Toll-IL-1 receptor adaptor family grows to five members. Trends Immunol 24: 286-290, 2003.

14. Motshwene PG, Moncrieffe MC, Grossmann JG, Kao C, Ayaluru M, Sandercock AM, Robinson CV, Latz E and Gay NJ: An oligomeric signaling platform formed by the Toll-like receptor signal transducers MyD88 and IRAK-4. J Biol Chem 284: 25404-25411, 2009.

15. Gay NJ, Symmons MF, Gangloff M and Bryant CE: Assembly and localization of Toll-like receptor signalling complexes. Nat Rev Immunol 14: 546-558, 2014.

16. Jardin F: Next generation sequencing and the management of diffuse large B-cell lymphoma: From whole exome analysis to targeted therapy. Discov Med 18: 51-65, 2014.

17. Vermaat JS, Somers SF, de Wreede LC, Kraan W, de Groen RA, Schrader AM, Kerver ED, Scheepstra CG, Berenschot H, Deenik W, et al: MYD88 mutations identify a molecular subgroup of diffuse large B-cell lymphoma with an unfavourable prognosis. Haematologica 105: 424-434, 2020.

18. Montesinos-Rongen M, Godlewska E, Brunn A, Wiestler OD, Siebert R and Deckert M: Activating L265P mutations of the MYD88 gene are common in primary central nervous system lymphoma. Acta Neuropathol 122: 791-792, 2011.

19. Takano S, Hattori K, Ishikawa E, Narita Y, Iwadate Y, Yamaguchi F, Nagane M, Akimoto J, Oka H, Tanaka S, et al: MyD88 mutation in the elderly predicts a poor prognosis in primary CNS lymphoma: Multi-institutional analysis. World Neurosurg 112: e69-e73, 2018.

20. Pham-Ledard A, Beylot-Barry M, Barbe C, Leduc M, Petrella T, Vergier B, Martinez F, Cappellen D, Merlio JP and Grange F: High frequency and clinical prognostic value of MYD88 L265P mutation in primary cutaneous diffuse large B-cell lymphoma, leg-type. JAMA Dermatol 150: 1173-1179, 2014. 
21. Kraan W, van Keimpema M, Horlings HM, Schilder-Tol EJ, Oud ME, Noorduyn LA, Kluin PM, Kersten MJ, Spaargaren M and Pals ST: High prevalence of oncogenic MYD88 and CD79B mutations in primary testicular diffuse large B-cell lymphoma. Leukemia 28: 719-720, 2014

22. Varettoni M, Arcaini L, Zibellini S, Boveri E, Rattotti S, Riboni R, Corso A, Orlandi E, Bonfichi M, Gotti M, et al: Prevalence and clinical significance of the MYD88 (L265P) somatic mutation in Waldenstrom's macroglobulinemia and related lymphoid neoplasms. Blood 121: 2522-2528, 2013.

23. Xu L,Hunter ZR, Yang G, Zhou Y, Cao Y,Liu X, Morra E, Trojani A, Greco A, Arcaini L, et al: MYD88 L265P in Waldenström macroglobulinemia, immunoglobulin $\mathrm{M}$ monoclonal gammopathy, and other B-cell lymphoproliferative disorders using conventional and quantitative allele-specific polymerase chain reaction. Blood 121: 2051-2058, 2013.

24. Treon SP, Xu L, Yang G, Zhou Y, Liu X, Cao Y, Sheehy P, Manning RJ, Patterson CJ, Tripsas C, et al: MYD88 L265P somatic mutation in Waldenström's macroglobulinemia. N Engl J Med 367: 826-833, 2012.

25. Schmitz R, Wright GW, Huang DW, Johnson CA, Phelan JD, Wang JQ, Roulland S, Kasbekar M, Young RM, Shaffer AL, et al: Genetics and Pathogenesis of Diffuse Large B-Cell Lymphoma. N Engl J Med 378: 1396-1407, 2018.

26. Weber AN, Cardona Gloria Y, Çınar Ö, Reinhardt HC, Pezzutto A and Wolz OO: Oncogenic MYD88 mutations in lymphoma: Novel insights and therapeutic possibilities. Cancer Immunol Immunother 67: 1797-1807, 2018.

27. Arber DA, Orazi A, Hasserjian R, Thiele J, Borowitz MJ, Le Beau MM, Bloomfield CD, Cazzola M and Vardiman JW: The 2016 revision to the World Health Organization classification of myeloid neoplasms and acute leukemia. Blood 127: 2391-2405, 2016.

28. World Medical Association: World Medical Association Declaration of Helsinki: Ethical Principles for Medical Research Involving Human Subjects. JAMA, 310, 2191-2194, 2013.

29. Choi JW, Kim Y, Lee JH and Kim YS: MYD88 expression and L265P mutation in diffuse large B-cell lymphoma. Human Pathology 44: 1375-1381, 2013.

30. Wang J, Gao K, Lei W, Dong L, Xuan Q, Feng M, Wang J, Ye X, Jin T, Zhang Z, et al: Lymphocyte-to-monocyte ratio is associated with prognosis of diffuse large B-cell lymphoma: Correlation with CD163 positive M2 type tumor-associated macrophages, not PD-1 positive tumor-infiltrating lymphocytes. Oncotarget 8: 5414-5425, 2017.

31. Hermine O, Haioun C, Lepage E, d'Agay MF, Briere J, Lavignac C, Fillet G, Salles G, Marolleau JP, Diebold J, et al: Prognostic Significance of bcl-2 Protein Expression in Aggressive Non-Hodkin's Lymphoma. Blood 87: 265-272, 1996.

32. Reed JC, Miyashita T, Takayama S, Wang HG, Sato T, Krajewski S, Aimé-Sempé C, Bodrug S, Kitada S and Hanada M: BCL-2 family proteins: Regulators of cell death involved in the pathogenesis of cancer and resistance to therapy. J Cell Biochem 60: 23-32, 1996.

33. Xu Y, Li J, Ouyang J, Li J, Xu J, Zhang Q, Yang Y, Zhou M, Wang J, Zhang C, et al: Prognostic relevance of protein expression, clinical factors, and MYD88 mutation in primary bone lymphoma. Oncotarget 8: 65609-65619, 2017.

34. Treon SP, Gustine J, Xu L, Manning RJ, Tsakmaklis N, Demos M, Meid K, Guerrera ML, Munshi M, Chan G, et al: MYD88 wild-type Waldenstrom Macroglobulinaemia: Differential diagnosis, risk of histological transformation, andoverall survival. Br J Haematol 180: 180,2017

35. Abeykoon JP,Paludo J,King RL, Ansell SM, Gertz MA,LaPlant BR, Halvorson AE, Gonsalves WI, Dingli D, Fang H, et al: MYD88 mutation status does not impact overall survival in Waldenström macroglobulinemia. Am J Hematol 93: 187-194, 2018.

36. Lee YS, Liu J, Fricano KA, Webb EM, Toolsie DR, Jones S, Rhoads JA, Vij R, Cashen AF, Abboud CN, et al: Lack of a prognostic impact of the MyD88 L265P mutation for diffuse Large B cell lymphoma patients undergoing autologous stem cell transplantation. Biol Blood Marrow Transplant 23: 2199-2204, 2017.

37. Lee JH, Jeong H, Choi JW, Oh H and Kim YS: Clinicopathologic significance of MYD88 L265P mutation in diffuse large B-cell lymphoma: A meta-analysis. Sci Rep 7: 1785, 2017.

38. Dong T, Liu Z, Xuan Q, Wang Z, Ma W and Zhang Q: Tumor LDH-A expression and serum LDH status are two metabolic predictors for triple negative breast cancer brain metastasis. Sci Rep 7: 6069, 2017

39. Motzer RJ, Escudier B, Bukowski R, Rini BI, Hutson TE, Barrios CH, Lin X, Fly K, Matczak E and Gore ME: Prognostic factors for survival in 1059 patients treated with sunitinib for metastatic renal cell carcinoma. Br J Cancer 108: 2470-2477, 2013.
40. Biccler J, Eloranta S, de Nully Brown P, Frederiksen H, Jerkeman M, Smedby KE, Bøgsted M and El-Galaly TC: Simplicity at the cost of predictive accuracy in diffuse large B-cell lymphoma: A critical assessment of the R-IPI,IPI, and NCCN-IPI. Cancer Med 7: 114-122, 2018.

41. Stotz M, Pichler M, Absenger G, Szkandera J, Arminger F, Schaberl-Moser R, Samonigg H, Stojakovic T and Gerger A: The preoperative lymphocyte to monocyte ratio predicts clinical outcome in patients with stage III colon cancer. Br J Cancer 110: 435-440, 2014.

42. Motomura T, Shirabe K, Mano Y, Muto J, Toshima T, Umemoto Y, Fukuhara T, Uchiyama H, Ikegami T, Yoshizumi T, et al: Neutrophil-lymphocyte ratio reflects hepatocellular carcinoma recurrence after liver transplantation via inflammatory microenvironment. J Hepatol 58: 58-64, 2013.

43. Kantola T, Klintrup K, Väyrynen JP, Vornanen J, Bloigu R, Karhu T, Herzig KH, Näpänkangas J, Mäkelä J, Karttunen TJ, et al: Stage-dependent alterations of the serum cytokine pattern in colorectal carcinoma. Br J Cancer 107: 1729-1736, 2012.

44. Hans CP, Weisenburger DD, Greiner TC, Gascoyne RD, Delabie J, Ott G, Müller-Hermelink HK, Campo E, Braziel RM, Jaffe ES, et al: Confirmation of the molecular classification of diffuse large B-cell lymphoma by immunohistochemistry using a tissue microarray. Blood 103: 275-282, 2004.

45. Davis RE, Ngo VN, Lenz G, Tolar P, Young RM, Romesser PB, Kohlhammer H, Lamy L, Zhao H, Yang Y, et al: Chronic active B-cell-receptor signalling in diffuse large B-cell lymphoma. Nature 463: 88-92, 2010.

46. Compagno M, Lim WK, Grunn A, Nandula SV, Brahmachary M, Shen Q, Bertoni F, Ponzoni M, Scandurra M, Califano A, et al: Mutations of multiple genes cause deregulation of NF-kappaB in diffuse large B-cell lymphoma. Nature 459: 717-721, 2009.

47. Davis RE, Brown KD, Siebenlist U and Staudt LM: Constitutive nuclear factor kappaB activity is required for survival of activated B cell-like diffuse large B cell lymphoma cells. J Exp Med 194: 1861-1874, 2001.

48. Frick M, Bettstetter M, Bertz S, Schwarz-Furlan S, Hartmann A, Richter T, Lenze D, Hummel M, Dreyling M, Lenz G, et al: Mutational frequencies of CD79B and MYD88 vary greatly between primary testicular DLBCL and gastrointestinal DLBCL. Leuk Lymphoma 59: 1260-1263, 2018.

49. Chapuy B, Roemer MG, Stewart C, Tan Y, Abo RP, Zhang L, Dunford AJ, Meredith DM, Thorner AR, Jordanova ES, et al: Targetable genetic features of primary testicular and primary central nervous system lymphomas. Blood 127: 869-881, 2016.

50. Ollila TA and Olszewski AJ: Extranodal diffuse large B cell lymphoma: Molecular features, prognosis, and risk of central nervous system recurrence. Curr Treat Options Oncol 19: 38, 2018.

51. Hattori K, Sakata-Yanagimoto M, Okoshi Y, Goshima Y, Yanagimoto S, Nakamoto-Matsubara R, Sato T, Noguchi M, Takano S, Ishikawa E, et al: MYD88 (L265P) mutation is associated with an unfavourable outcome of primary central nervous system lymphoma. Br J Haematol 177: 492-494, 2017.

52. Fox LC, Yannakou CK, Ryland G, Lade S, Dickinson M, Campbell BA and Prince HM: Molecular mechanisms of disease progression in primary cutaneous diffuse large B-cell lymphoma, leg type during ibrutinib therapy. Int J Mol Sci 19: 1758, 2018.

53. Li XQ, Li GD, Gao ZF, Zhou XG and Zhu XZ: Distribution pattern of lymphoma subtypes in China: A nationwide multicenter study of 10002 cases. J Diagn Concepts Pract 11: 111-115, 2012.

54. Komatsubara KM and Sacher AG: Circulating tumor DNA as a liquid biopsy: Current clinical applications and future directions. Oncology (Williston Park) 31: 618-627, 2017.

55. Drandi D, Genuardi E, Dogliotti I, Ferrante M, Jiménez C, Guerrini F, Schirico ML, Mantoan B, Vittorio Muccio V, Lia G, et al: Highly sensitive MYD88L265P mutation detection by droplet digital PCR in Waldenström macroglobulinemia. Haematologica 103: 1029-1037, 2018.

56. Hiemcke-Jiwa LS, Minnema MC, Radersma-van Loon JH, Jiwa NM, de Boer M, Leguit RJ, de Weger RA and Huibers MM: The use of droplet digital PCR in liquid biopsies: A highly sensitive technique for MYD88 p.(L265P) detection in cerebrospinal fluid. Hematol Oncol 36: 429-435, 2018.

This work is licensed under a Creative Commons Attribution-NonCommercial-NoDerivatives 4.0 International (CC BY-NC-ND 4.0) License. 